\title{
Comparative study of binding strengths of heavy metals with humic acid
}

\author{
Ivana S. Kostić ${ }^{1}$, Tatjana D. Anđelković ${ }^{1}$, Ružica S. Nikolić ${ }^{1}$, Tatjana P. Cvetković́ ${ }^{2}$, Dušica D. Pavlović ${ }^{2}$, \\ Aleksandar Lj. Bojić ${ }^{1}$ \\ ${ }^{1}$ University of Niš, Faculty of Science and Mathematics, Višegradska 33, 18000 Niš, Serbia \\ ${ }^{2}$ University of Niš, Faculty of Medicine, Bul. Zorana Đinđića 81, 18000 Niš, Serbia
}

\begin{abstract}
The complexation of humic acid with certain heavy metal ions (Co(II), Ni(II), $\mathrm{Cu}(\mathrm{II}), \mathrm{Zn}$ (II) and $\mathrm{Pb}(\mathrm{II})$ ) was investigated. The stability constants of humate complexes were determined by a method based on the distribution of metal ions between solution and resin in the presence and the absence of ligand, known as Schubert's ion exchange method. Experiments were performed at $25^{\circ} \mathrm{C}, \mathrm{pH} 4.0$ and ionic strength of $0.01 \mathrm{~mol} \mathrm{dm}^{-3}$. It was found that the 1:1 complexes were formed between metal ions and humic acid. Obtained results of the stability constants, $\log \beta_{\mathrm{mn}}$, of complexes formed between the metal ions and humic acid follow the order $\mathrm{Co}(\mathrm{II})<\mathrm{Ni}$ (II) $<\mathrm{CU}(\mathrm{II})>\mathrm{Zn}$ (II), which is the same as in the Irving-Williams series for the binding strength of divalent metal ion complexes. The stability constant of complex between $\mathrm{Pb}$ (II) ions and humic acid is greater than the stability constants of other investigated metal-humate complexes. The investigation of interaction between heavy metal ions and humics is important for the prediction of the distribution and control of the migration of heavy metals in natural environment.
\end{abstract}

Keywords: heavy metal pollution, humic acid, stability constant.

\section{SCIENTIFIC PAPER}

UDC 502/504:504.5:547.992

Hem. Ind. 67 (5) 773-779 (2013)

doi: 10.2298/HEMIND121107002K

Available online at the Journal website: http://www.ache.org.rs/HI/

Heavy metals contamination of the environment is a threat to all living organisms. Since the metals are not biodegraded and that many of them are soluble in water, they can become more available for living systems and can accumulate in the environment [1]. Defining the factors that affect their bioavailability, leaching and toxicity in soil/water systems is of crucial importance.

Industrial discharge to the atmosphere, soil and water is the most important source that contributes to increased concentrations of heavy metals in the environment. The greatest heavy metal dispersion is observed in areas with metallurgy industries. During the processing of ore, the heavy metals, which occur in nature at very low concentrations, are released into the environment in high concentrations [2]. Around 100 times more lead $(\mathrm{Pb}), 13$ times more copper $(\mathrm{Cu})$ and 21 times more zinc $(\mathrm{Zn})$ is emitted to the atmosphere by human activities than by natural processes. These industrial areas can be considered as risk areas with regard to trace metals and need to have discharge control or in some cases remediation strategy. These metal ions under certain conditions favor the interaction with functional groups such as carboxylic, phenolic, alcoholic, enolic $-\mathrm{OH}$ and amino groups. All this shows the necessity for improving the knowledge

Correspondence: I. Kostić, Faculty of Science and Mathematics, Višegradska 33, 18000 Niš, Serbia.

E-mail: ivana.kostic83@gmail.com

Paper received: 7 November, 2012

Paper accepted: 19 December, 2012 about heavy metals behavior in soils and waters in order to make accurate risk assessments for human health, define long-term ecological effects, set limit values and identify priorities in remediation of contaminated sites [3].

Heavy metals can be involved in a series of complex chemical and biological interactions. Factors that affect their mobility through the soil/water system are $\mathrm{pH}$, redox status of the environment, sorbent nature, presence and amount of organic and inorganic ligands, including humic and fulvic acids, root exudates and nutrients [4].

Humic acids have natural and powerful adsorbent properties and are deeply related to the transportation and accumulation of heavy metals [5,6]. They are widely distributed in soils/waters and the type and structure of their functional groups depend on their genesis, but also on the method of their isolation and purification $[7,8]$. They control the behavior of heavy metals in the environment and their interactions with metals are complex, depending on the characteristics of humic acid, concentration of metal ions, $\mathrm{pH}$ value, etc. [9]. The complexation of humic acid with metals can affect the fate of metals in soils and waters, thus speciation of metals is affected by these complexes as well as oxidation-reduction reactions. Humic acid can serve as carrier of toxic metals, forming complexes that are stable and enhance transport of toxic metals in waters [10-12].

Environmental implication of humic-metal binding depends on the possibility whether metal ions form soluble humic complexes that can potentially conta- 
minate groundwater and retain the metal in soil solution or metal ions form insoluble humic complexes that will result in a reduction of bioavailability and ecotoxicity of the metals $[12,13]$. Studies of interactions between humic substances and heavy metals are mainly focused on estimating stability constants at a specific $\mathrm{pH}$ and ionic strength $[8,9]$. Thus, complexation of heavy metals in the environment is usually assumed or extrapolated for the complex natural system that involve a large number of different parameters (presence of competition ions, dissolved and particular organic matter, etc.). Therefore, investigation of the mechanism of interaction between heavy metal ions and humics is very important for the prediction of the distribution and control of the migration of heavy metals in natural environment [12-14].

Humic matter-metal ion stability constants are determined by a variety of different analytical techniques such as: centrifugation-depletion, equilibrium dialysis, ultrafiltration, chromatography, diffusive gradients in thin films, etc. Competitive methods are Schubert's method, competing dissolved ligand and kinetic discrimination [15].

The aim of this paper is to predict the behavior of heavy metals regarding the presence of humic acid in the environment, based on the strength of formed complexes. We have determined stability constants of five transition metals by using Schubert's cation exchange equilibrium method. The results confirm that Schubert's method can be used not only for stoichiometrically defined ligands but also for complexes of polyfunctional and stoichiometrically undefined ligands, such humic ligands are. Finding the relative order of metal-humic complexes stabilities can help in estimation of the fate transport and distribution of heavy metals through different compartments of the environment [16-18].

\section{EXPERIMENTAL}

\section{Chemical reagents and instrumentation}

Stock solutions of each metal were prepared from metal salts $\left(\mathrm{Pb}\left(\mathrm{NO}_{3}\right)_{2}, \mathrm{CuCl}_{2} \cdot 2 \mathrm{H}_{2} \mathrm{O}, \mathrm{Zn}\left(\mathrm{NO}_{3}\right)_{2} \cdot 6 \mathrm{H}_{2} \mathrm{O}\right.$, $\mathrm{Co}\left(\mathrm{NO}_{3}\right)_{2} \cdot 6 \mathrm{H}_{2} \mathrm{O}$ and $\left.\mathrm{Ni}\left(\mathrm{SO}_{4}\right)_{2} \cdot 6 \mathrm{H}_{2} \mathrm{O}\right)$. All metal salts were of analytical grade purity (purchased from Merck, Germany). Humic acid was purchased from Aldrich (HA, catalog H1, 675-2 lot No. S15539-264). All solutions were prepared using deionized water (conductivity less than $0.1 \mu \mathrm{S} \mathrm{cm}{ }^{-1}$ ). Measurements of $\mathrm{pH}$ were made with a sensION MM 374 (precision 0.01 units of $\mathrm{pH}$ ) using a HACH gel-filled glass electrode (LZW 5010 t.97.002). The $\mathrm{pH}$ electrode was standardized using commercially prepared $\mathrm{pH} 4.1,7.0$ and 10.0 buffers. The prepared solutions were analyzed by flame atomic absorption spectroscopy (FAAS) using an AAnalyst 300 (Perkin Elmer) instrument.

\section{Experimental procedure of resin preparation}

The cation-exchange resin used in determination of stability constants was Dowex 50WX8, 100-200 mesh, Na-form, withan exchange capacity of $1.7 \mathrm{meq} \mathrm{cm}^{-3}$. About $30 \mathrm{~g}$ of the resin was prepared by transferring to a glass column, and sequentially rinsing with $2 \mathrm{dm}^{3}$ of deionized water, $2 \mathrm{dm}^{3}$ of $2 \mathrm{~mol} \mathrm{dm^{-3 }} \mathrm{HCl}, 2 \mathrm{dm}^{3}$ of 2 mol $\mathrm{dm}^{-3} \mathrm{NaOH}$ and finally with $2 \mathrm{dm}^{3}$ of deionized water. The resin was changed in Na-form by passing 2 $\mathrm{dm}^{3}$ of $2 \mathrm{~mol} \mathrm{dm}^{-3} \mathrm{NaCl}$, followed by rinsing with $2 \mathrm{dm}^{3}$ deionized water. The resin was then air-dried for $24 \mathrm{~h}$ and stored in an air-tight polyethylene container.

Experimental procedure for establishing metal(II) ionexchange isotherms $\left(D_{0}\right)$ and determination of conditional stability constant of metal-ligand complexes

lon-exchange isotherm was measured at $\mathrm{pH} 4.0$ for each metal (Cu(II), $\mathrm{Pb}(\mathrm{II}), \mathrm{Ni}(\mathrm{II}), \mathrm{Zn}(\mathrm{II})$ and $\mathrm{Co}(\mathrm{II}))$. Metal concentration solutions ranged from 5 to $20 \mathrm{mg} \mathrm{dm}^{-3}$. For each measurement, metal solutions were prepared by adding different volumes of metal stock solutions to $50.0 \mathrm{~cm}^{3}$ volumetric flask along with $0.01 \mathrm{~mol} \mathrm{dm}^{-3}$ $\mathrm{NaCl}$, and adjustment of $\mathrm{pH}$ with the addition of 0.1 mol $\mathrm{dm}^{-3} \mathrm{NaOH}$ and/or $0.1 \mathrm{~mol} \mathrm{dm^{-3 }} \mathrm{HCl}$. Accurately weighed $0.100 \mathrm{~g}$ of cleaned, Na-saturated cation exchange resin Dowex 50WX8 (100-200 mesh) was added to $50.0 \mathrm{~cm}^{3}$ of the prepared metal solutions. All samples were shaken for $2 \mathrm{~h}$, at constant temperature of $25^{\circ} \mathrm{C}$.

The ion-exchange procedure used to determine stability constants for ligands and divalent metal ion was similar to the procedure used to establish the distribution coefficient, $D_{0}$, with difference that the solution contained ligand. Each solution contained variable concentration of metal ions, from 5 to $20 \mathrm{mg} \mathrm{dm}^{-3}$ for each metal, and concentration of humic acid, from 0.005 to $0.015 \mathrm{~mol} \mathrm{dm}^{-3}$. The solution was adjusted to $\mathrm{pH} 4.0,0.100 \mathrm{~g}$ of resin in the Na-form was added and solutions were equilibrated under the same conditions as previous. Each determination was carried out in triplicate.

\section{RESULTS AND DISCUSSION}

The ion-exchange equilibrium method originally developed by Schubert, and first applied to water soluble organic matter complexes by Miller and Ohlrogge, is the most attractive procedure for the determination of stability constants $[19,20]$. The equilibrium reaction for chelate or complex formation can be written as: 
$\mathrm{M}+n \mathrm{~L} \rightarrow \mathrm{ML}_{n}$

$K=\frac{[\mathrm{M}][\mathrm{L}]^{n}}{\left[\mathrm{ML}_{n}\right]}$

The distribution coefficient, $D_{0}$, between the resin and solution phase for metal ion in the absence of ligand and the distribution coefficient, $D$, between the resin and solution phase for metal ion in the presence of ligand was calculated by equilibrium ratio:

$D_{0}=\frac{\alpha_{0} V}{\left(100-\alpha_{0}\right) m_{\mathrm{r}}}$

where $\alpha_{0}$ is the percentage of total metal bound to exchange resin; $\left(100-\alpha_{0}\right)$ is the percentage of total metal remaining in solution; $V$ is the volume of solution $\left(\mathrm{cm}^{3}\right)$ and $m_{\mathrm{r}}$ is the weight of exchange resin $(\mathrm{g})$.

The number of equivalents of the complexing agent, $n$, combined with a particular metal ion was found from the slope of the linear function:

$\log \left(\frac{D_{0}}{D}-1\right)=\log \beta_{\mathrm{mn}}+n \log c_{\mathrm{L}}$

where $c_{\mathrm{L}}$ is the concentration of ligand $\left(\mathrm{mol} \mathrm{dm}^{-3}\right)$.

Equation (4) is used to determine conditional stab- ility constants for mononuclear complexes. Possible problems with the Schubert's method occur when the complex, $\mathrm{M}_{m} \mathrm{~L}_{n}$, is not mononuclear $(m \neq 1)$. The following equation of the modified Schubert's method is used to eliminate this source of errors and presents the modified method of data treatment and analysis:

$$
\begin{aligned}
& \log M_{\mathrm{c}}=\log \left(\frac{D_{0}}{D}-1\right)= \\
& =\log m+\log \beta_{\mathrm{mn}}+(m-1) \log M+n \log c_{\mathrm{L}}
\end{aligned}
$$

Equation (5) is used to calculate the $\log \beta_{\mathrm{mn}}$ for polynuclear complexes. Equation (4) is a reduced form of Eq. (5) for the case when $m=1$, when a mononuclear complex is present [21-23].

The isotherms for each metal ion were investigated at $25{ }^{\circ} \mathrm{C}$ temperature and $\mathrm{pH} 4.0$ in order to avoid hydrolysis of metal ions and carbonate formation. Humic acid was characterized in detail previously [24].

The isotherm linear range was obtained for each metal, in order to estimate $D_{0}$ and choose the appropriate concentrations for preventing the effect of metal loading [21-24].

Table 1 gives a summary of the percentage of total metal bound to exchange resin, $\alpha_{0}$, distribution coefficient between the resin and solution phase for metal ion in the absence $\left(D_{0}\right)$ and presence $(D)$ of ligand for

Table1. Experimentally determined percentage of total metal bound to exchange resin, $\alpha_{0}$, distribution coefficients, $D_{0}$, metal-ligand ratio and logarithm of conditional stability constant, log $\beta_{m n}$ for complexes $\mathrm{Pb}(\mathrm{II}), \mathrm{Cu}(\mathrm{II}), \mathrm{Zn}(\mathrm{II}), \mathrm{Ni}(\mathrm{II})$ and $\mathrm{Co}(\mathrm{II})\left(5 \mathrm{mg} d \mathrm{~m}^{-3}\right)$ with

\begin{tabular}{|c|c|c|c|c|c|c|c|}
\hline \multirow{2}{*}{ Metal ion } & \multirow{2}{*}{$c_{\mathrm{HA}} \times 10^{3} / \mathrm{mol} \mathrm{dm}^{-3}$} & \multirow{2}{*}{$\alpha_{0}$} & \multirow{2}{*}{$D_{0}$} & \multirow{2}{*}{$D$} & \multirow{2}{*}{$\log \left(D_{0} /(D-1)\right)$} & \multicolumn{2}{|c|}{$\log \beta_{\mathrm{mn}}$} \\
\hline & & & & & & Determined & Mean \\
\hline \multirow[t]{4}{*}{$\mathrm{Co}(\mathrm{II})$} & 0 & 61.14 & 786.67 & - & - & - & 1.95 \\
\hline & 5 & 50.36 & & 507.25 & -0.259 & 2.04 & \\
\hline & 10 & 46.46 & & 433.88 & -0.090 & 1.91 & \\
\hline & 20 & 41.78 & & 358.81 & 0.076 & 1.89 & \\
\hline \multirow[t]{4}{*}{$\mathrm{Ni}(\mathrm{II})$} & 0 & 12.48 & 71.30 & - & - & - & 2.24 \\
\hline & 5 & 6.94 & & 37.29 & -0.040 & 2.26 & \\
\hline & 10 & 4.84 & & 25.43 & 0.256 & 2.26 & \\
\hline & 20 & 4.10 & & 21.37 & 0.368 & 2.19 & \\
\hline \multirow[t]{4}{*}{$\mathrm{Cu}(\mathrm{II})^{\mathrm{a}}$} & 0 & 58.52 & 705.4 & - & - & - & 2.33 \\
\hline & 5 & 49.28 & & 485.80 & -0.347 & 2.25 & \\
\hline & 10 & 27.00 & & 184.93 & 0.449 & 2.45 & \\
\hline & 20 & 20.84 & & 131.63 & 0.639 & 2.29 & \\
\hline \multirow[t]{4}{*}{$\mathrm{Zn}(\mathrm{II})$} & 0 & 31.04 & 225.06 & - & - & - & 2.25 \\
\hline & 5 & 18.74 & & 115.31 & -0.021 & 2.28 & \\
\hline & 10 & 14.46 & & 84.522 & 0.221 & 2.22 & \\
\hline & 20 & 11.02 & & 61.924 & 0.421 & 2.24 & \\
\hline \multirow[t]{4}{*}{$\mathrm{Pb}(\mathrm{II})^{\mathrm{a}}$} & 0 & 52.56 & 553.96 & - & - & - & 2.50 \\
\hline & 5 & 29.40 & & 208.21 & 0.220 & 2.52 & \\
\hline & 10 & 24.20 & & 159.63 & 0.393 & 2.39 & \\
\hline & 20 & 14.00 & & 81.39 & 0.764 & 2.59 & \\
\hline
\end{tabular}
humic acid, at $\mathrm{pH} 4.0$ and ionic strength of $I=0.01 ; M: L=1: 1$

${ }^{\mathrm{a}}$ Results for $\mathrm{Cu}(\mathrm{II})$ and $\mathrm{Pb}(\mathrm{II})$ are previously reported and are taken from reference [24] 
each of five metals, and values of stability constants, $\log \beta_{\mathrm{mn}}$. The presented results show the obtained parameters only for $5 \mathrm{mg} \mathrm{dm}^{-3}$ metal ions concentration, while the investigations were done at 10,15 and $20 \mathrm{mg}$ $\mathrm{dm}^{-3}$ metal ions concentrations as well.

The results in Table 1 show that the percentage of total metal bound to exchange resin, $\alpha_{0}$, for $\mathrm{Co}$ (II) was $61.14 \%$ and was the highest comparing to other metal ions $\mathrm{Cu}(\mathrm{II})$ (58.52\%), $\mathrm{Pb}$ (II) (52.56\%), $\mathrm{Zn}(\mathrm{II})(31.04 \%)$ and $\mathrm{Ni}(\mathrm{II})(12.48 \%)$. For each metal ion, the percentage of total metal bound to the exchange resin, $\alpha_{0}$, decreased with increase of humic acid concentration. This trend was expected because by increasing humic acid concentration, the number of binding sites increases and therefore, the amount of metal absorbed on the resin is reduced.

Figure 1 presents plots of $\log \left(D_{0} /(D-1)\right) v s . \log c_{\mathrm{L}}$ for each metal ion at four concentrations.

The slopes of the plots presented in Figure 1 give the composition of complexes. Values of $n$ close to unity indicate that the metal ligand ratio in these complexes is 1:1. Also, Figure 1 shows that the stability sequence of the metal ions under the given conditions is: $\mathrm{Co}$ (II) $<\mathrm{Ni}$ (II) $<\mathrm{Zn}$ (II) $<\mathrm{Cu}$ (II) $<\mathrm{Pb}$ (II). All these transition metals tend to favor formation of a covalent or coordination bond with the humic ligand with partial or total breakdown of the hydration sphere of the metal. Thus, the investigated metals are more tightly held pre-

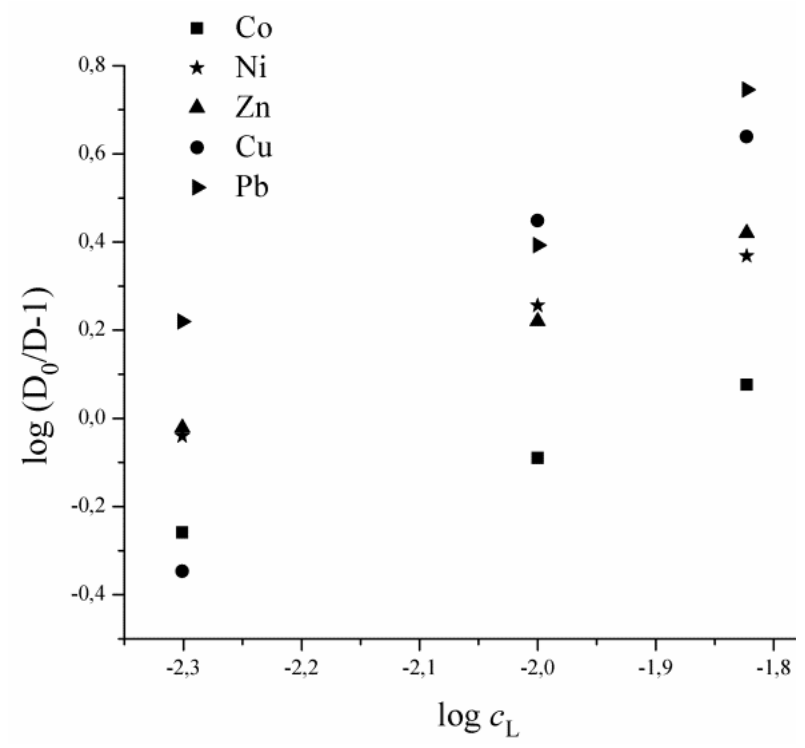

(a)

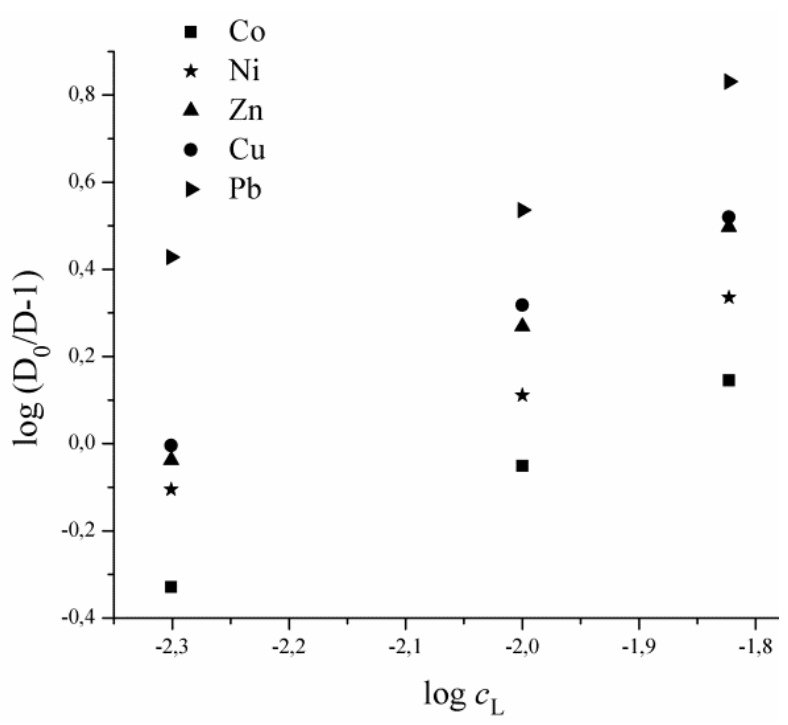

(c)

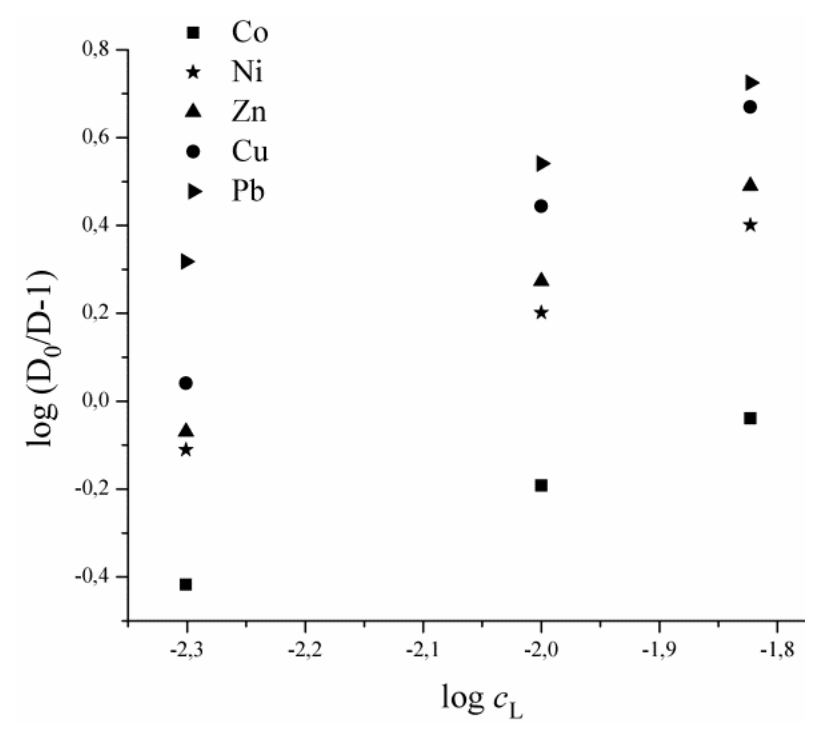

(b)

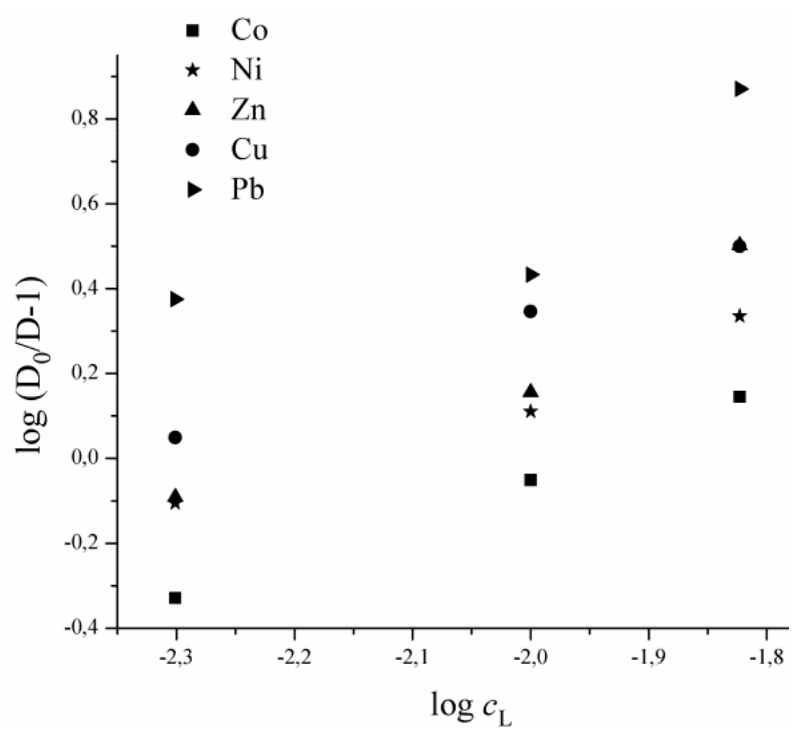

(d)

Figure 1. Schubert's plots of the ratio of complexed metal to free metal (log $\left(D_{0} /(D-1)\right)$ versus $\log c_{H A}$ for $P b(I I), C \mathrm{Cu}(I I), \mathrm{Zn}(I I), \mathrm{Ni}(I I)$ and $\mathrm{Co}(\mathrm{II})$ ions with humic acid and concentration of metal ion: a) 5; b) 10;c) 15 ; d) $20 \mathrm{mg} \mathrm{dm^{-3 }}$. 
ferably creating inner sphere complexes than for example, alkali and alkaline earth metals which tend to favor creation of outer sphere complexes, with bonds of purely electrostatic nature, where metal retain their hydration spheres [20].

The stability constants, $\log \beta_{\mathrm{mn}}$, and metal-ligand ratios for complexes between each concentration of $\mathrm{Pb}(\mathrm{II}), \mathrm{Cu}(\mathrm{II}), \mathrm{Zn}(\mathrm{II}), \mathrm{Ni}(\mathrm{II})$ and $\mathrm{Co}(\mathrm{II})$ ions with humic acid are summarized in Table 2.

The obtained stability constants, $\log \beta_{\mathrm{mn}}$, show that the investigated divalent ions follow the Irving-Williams series type: $\mathrm{Co}(\mathrm{II})<\mathrm{Ni}(\mathrm{II})<\mathrm{Cu}(\mathrm{II})>\mathrm{Zn}$ (II) for the binding strength of divalent metal ion complexes in complexation with humic acid, therefore to interact according to the basic principles of the formation of the complex. The Irving-Williams order is based on empirical observation and related to both the increase of effective nuclear charge and increase of atomic number. The position of $\mathrm{Cu}(\mathrm{II})$ in the Irving-Williams order is considered out-of-line ( $\mathrm{Mn}$ (II) $<\mathrm{Fe}$ (II) $<\mathrm{Co}$ (II) $<\mathrm{Ni}$ (II) $<$ $<\mathrm{Cu}(\mathrm{II})>\mathrm{Zn}(\mathrm{II}))$, probably as a consequence of the fact that $\mathrm{Cu}(\mathrm{II})$ often forms distorted octahedral complexes. The different affinity of $\mathrm{Pb}(\mathrm{II}), \mathrm{Cu}(\mathrm{II}), \mathrm{Zn}(\mathrm{II}), \mathrm{Ni}(\mathrm{II})$ and Co(II) can be explained by their chemical properties such as the size of ion radius $\left(r_{\mathrm{M}}{ }^{2+}\right)$, charge $(z)$ of the metal ion, that is ionic potential, $I p=z / r$, the electronegativity of the element, ligand field stabilization energy effects and classification, which is based on the electron configuration of the cations and the concept of hard/soft acids and bases (HSAB theory) $[23,24]$.

Stability constants obtained for complexes between $\mathrm{Cu}(\mathrm{II}), \mathrm{Zn}(\mathrm{II}), \mathrm{Ni}(\mathrm{II})$ and $\mathrm{Co}(\mathrm{II})$ and humic acid were founded to be smaller than stability constant obtained for $\mathrm{Pb}$ (II) humate complex, which can be explained with HSAB theory. Humic acids behave as weak acid polyelectrolytes with a variety of oxygen containing functional groups such as carboxylic, hydroxyl, phenolic and carbonyl, with oxygen as a donor atom show hard base properties (high electronegative atom) and make strong bonds with hard acids. According to the HSAB theory, cations $\mathrm{Pb}$ (II) and $\mathrm{Cu}$ (II) form stronger complexes with humic acids than with $\mathrm{Co}$ (II) and $\mathrm{Zn}$ (II). The affinity of the metals to humic acid can also be expected to increase in line with increasing electronegativity. This seems to be true for $\mathrm{Cu}(\mathrm{II}), \mathrm{Ni}(\mathrm{II}), \mathrm{Zn}(\mathrm{II})$ and $\mathrm{Co}(\mathrm{II})$, but not for $\mathrm{Pb}(\mathrm{II})$. The tendency of cations to form inner-sphere complexes with humic acid increases with increasing ionic potential $(I p)$. For the group of divalent metal ions this means that the smaller the radius of the ion is, the more likely it is to be found in an innersphere complex. Inner-sphere complexes are usually much stronger than outer-sphere complexes associated with a hydrated cation and an anion held by long-range electrostatic forces $[23,25]$.

Despite its low $\mathrm{Ip}$, the $\mathrm{Pb}(\mathrm{II})$-ion's great affinity to humic acid may be explained by itsborderline acid properties. The electronic configuration of the $\mathrm{Pb}(\mathrm{II})$ ion is $(n-1) 18 \mathrm{e}^{-}+n 2 \mathrm{e}^{-}$, which classifies it as aborderline metal acid and results in greater stability of the $\mathrm{Pb}(\mathrm{II})-$ -humate complex comparing to other complexes. On the other hand, $\mathrm{Cu}$ (II) and $\mathrm{Zn}$ (II) are classified as soft acids and do not form stable complexes with O-donor ligands, although should have high ability to coordinate with bases which contain $\mathrm{N}$ and/or $\mathrm{S}$ as donor ligands. According to this rule, the stability constant of complexes between these ions and humic acid is lower than the stability constant of $\mathrm{Pb}(\mathrm{II})$-humate complex. Due to the large ion size of $\mathrm{Pb}(\mathrm{II})$, the electrons are easily polarized and to a lesser degree retained by the nucleus [25].

Comparison of the obtained results for stability constants and stoichiometry of complexes $\mathrm{Pb}(\mathrm{II}), \mathrm{Cu}(\mathrm{II})$, $\mathrm{Zn}(\mathrm{II}), \mathrm{Ni}(\mathrm{II})$ and $\mathrm{Co}(\mathrm{II})$ with humic acid with literature data, indicate that the values are approximately equal. Variation of stability constants values in humic complexation studies is not uncommon due to differences in humic's elemental composition, their chemical structure and period of genesis during the humification process [20-22,26].

The established trend of metal-humate complexes stabilities can be used for predicting the strength of interaction between the humics and metal ions, as well as to predict their competition in binding to humate ligand. The obtained results indicate that there may be competition between these metal ions in the binding for humate macromolecules. Therefore, in conditions

Table 2.Stability constants, $\log \beta_{m n}$ and metal-ligand ratio for complexes of $\mathrm{Pb}(\mathrm{II}), \mathrm{Cu}(\mathrm{II}), \mathrm{Zn}(\mathrm{II}), \mathrm{Ni}(\mathrm{II})$ and $\mathrm{Co}(\mathrm{II})$ with humic acid, at $p H 4.0$ and ionic strength of $I=0.01 ; M: L=1: 1$

\begin{tabular}{|c|c|c|c|c|c|}
\hline \multirow{3}{*}{ Metal ion } & \multicolumn{4}{|c|}{$\log \beta_{\mathrm{mn}}$} & \multirow{3}{*}{$\begin{array}{c}\text { Literature values } \\
{[22,23,26-30]}\end{array}$} \\
\hline & \multicolumn{3}{|c|}{$c_{\mathrm{HA}} \times 10^{3} / \mathrm{mol} \mathrm{dm}^{-3}$} & \multirow{2}{*}{ Mean value } & \\
\hline & 5 & 10 & 15 & & \\
\hline $\mathrm{Co}(\mathrm{II})$ & 1.96 & 1.91 & 1.93 & 1.93 & $2.82-6.05$ \\
\hline $\mathrm{Ni}(\mathrm{II})$ & 2.21 & 2.17 & 2.18 & 2.19 & $1.56-3.20$ \\
\hline $\mathrm{Cu}(\mathrm{II})^{\mathrm{a}}$ & 2.31 & 2.39 & 2.36 & 2.35 & $1.95-5.28$ \\
\hline $\mathrm{Zn}(\mathrm{II})$ & 2.24 & 2.23 & 2.30 & 2.26 & $2.74-4.70$ \\
\hline $\mathrm{Pb}(\mathrm{II})^{\mathrm{a}}$ & 2.64 & 2.47 & 2.62 & 2.58 & $2.76-5.32$ \\
\hline
\end{tabular}

${ }^{\mathrm{a}}$ Results for $\mathrm{Cu}(\mathrm{II})$ and $\mathrm{Pb}(\mathrm{II})$ are previously reported and are taken from reference [24] 
of increased concentrations of metal ion in the natural environment, the metal ion may displace other ions, which can lead to increasing mobility and bioavailability of other metal ions.

The investigation reveals that humic acid can effectively bind heavy metals and due to this has potential to be used in remediation methods. For example, it can be used in wastewater treatment for heavy metal removal, as a metal detoxification agent for industrial and domestic effluents, which contain high levels of such heavy metals. Due to the ability to form complexes, humic acid also promotes retention and accumulation of heavy metals and thus, can be used in remediation processes.

\section{CONCLUSION}

Our results provide information on the interaction of $\mathrm{Pb}(\mathrm{II}), \mathrm{Cu}(\mathrm{II}), \mathrm{Zn}(\mathrm{II}), \mathrm{Ni}(\mathrm{II})$ and $\mathrm{Co}(\mathrm{II})$ with humic acid and distribution of those heavy metals through soil/ /water natural systems. Schubert's method can be used not only for stoichiometrically defined ligands but also for complexes of polyfunctional and stoichiometrically undefined ligands, such humic ligands are. The obtained results derived using Schubert's method indicate that the stability constant, $\log \beta_{\mathrm{mn}}$, for the $\mathrm{Pb}(\mathrm{II})$-humate complex was greater than that of other investigated humate complexes at $\mathrm{pH}$ 4.0. All investigated humic complexes showed 1:1 stoichiometry.

The established trend of metal-humate complexes stabilities, which follows the Irving-Williams series, can be used for predicting the strength of interaction between the humics and metal ions, thus for predicting mobility and bioavailability of metal ions.

\section{Acknowledgement}

This study was supported by the Ministry of Education, Science and Technological Development of the Republic of Serbia and was performed as a part of Project III41018.

\section{REFERENCES}

[1] A. Dube, R. Zbytniewski, T. Kowalkowski, E. Cukrowska, B. Buszewski, Pol. J. Environ. Stud. 10 (2001) 1-10.

[2] J.M. Garcia-Mina, Org. Geochem. 37 (2006) 1960-1972.

[3] S. Ross (ed.), Toxic Metals in Soil-Plant Systems, Wiley, New York, 1994.

[4] I. Christl, R. Kretzschmar, Environ. Sci. Technol. 35 (2001) 2505-2511.
[5] R. Sutton, G. Sposito, Environ. Sci. Technol. 23 (2005) 9009-9015.

[6] J.P. Gustafsson, P. Pechova, Environ. Sci. Technol. 37 (2003) 2767-2774.

[7] C.A. Coles, R. Yong, Eng. Geol. 85 (2006) 26-32.

[8] I.I. Lishtvan, F.N. Kaputskiy, Y.G. Yanuta, A.M. Abramets, V.P. Strigutskiy, E.V. Kachanova, Chem. Sustain. Dev.14 (2006) 267-373.

[9] I. Christl, C. Milne, D. Kinniburgh, R. Kretzschmar, Environ. Sci. Technol. 35 (2001) 2512-2517.

[10] D. Sparks, Environmental soil chemistry, $2^{\text {nd }}$ ed., Academic press, San Diego, CA, 1995.

[11] C. Rey-Castro, P. Lodeiro, R. Herrero, M. Sastre de Vicente, Environ. Sci. Technol. 37 (2003) 5159-5167.

[12] L.J. Evans, B. Sengdy, D.G. Lumsdon, D.A. Stanbury, Chem. Speciation Bioavail. 15 (2003) 93-100.

[13] T. Andjelković, J. Perović, M. Purenović, D. Andjelković, FactaUniversitatis, 3 (2004) 79-85.

[14] E. Tipping, Cation binding of humic substances, $1^{\text {st }}$ ed., Cambrige University Press, Cambrige, 2002.

[15] M. Schizer, S.U. Kahn, Humic substances in the Environment, Dekker, New York, 1972.

[16] J.M. de la Rosa, M. Santos, M.F. Araujo, Estaurine Coastal Shelf Sci. 93 (2011) 478-485.

[17] K. Furukawa, Y. Takahashi, Chemosphere 73 (2008) 1272-1278

[18] [18] S. Wang, C. N. Mulligan, Chemosphere 74 (2009) 274-279.

[19] J. Schubert, Theoret. J. Phys. Colloid Chem. 52 (1947) 340-350.

[20] J. Schubert, J. W. Richter, Theoret. J. Phys. Colloid Chem. 52 (1947) 350-357.

[21] H. Baker, F. Khalili, Anal. Chim. Acta 497 (2003) 235-248.

[22] H. Baker, F. Khalili, Anal. Chim. Acta 542 (2005) 240-248.

[23] H. Baker, F. Khalili, Ann. Environ. Sci. 1 (2007) 35-44.

[24] I. Kostić, T. Anđelković, R. Nikolić, A. Bojić, M. Purenović, S. Blagojević, D. Anđelković, J. Serb. Chem. Soc. 76 (2011) 1-12.

[25] F.A. Cotton, G. Wilkinson, C.A. Murillo, M. Bochmann, Advanced Inorganic Chemistry, $6^{\text {th }}$ ed., Wiley, New York, 1999.

[26] E. Giannakopoulos, K.C. Christoforidis, A. Tsipis, M. Jerzykiewicz, Y. Deligiannakis, J. Phys. Chem., A 109 (2005) 2223-2232.

[27] K. Gao, J. Pearce, J. Jones, C. Taylor, Environ. Geochem. Health 21 (1999) 13-26.

[28] K. Pandey, S.D. Pandey, V. Misra, Ecotoxicol. Environ. Saf. 47 (2000) 195-200.

[29] T.I. Nifant'eva, P. Burba, O. Fedorova, V.M. Shkinev, B. YaSpivakov, Talanta 53 (2001) 1127-1131.

[30] J.Z. Du, W.J. Li, H.Q. Zhang, X.D. Wang, Z.J. You, C.Y. Zhou, W.M. Dong, Z.Y. Tao, J. Radioanal. Nucl. Chem. 241 (1999) 651-654. 


\section{IZVOD}

\section{UPOREDNA ISPITIVANJA JAČINE VEZIVANJA JONA TEŠKIH METALA SA HUMINSKOM KISELINOM}

Ivana S. Kostić ${ }^{1}$, Tatjana D. Anđelković ${ }^{1}$, Ružica S. Nikolić ${ }^{1}$, Tatjana P. Cvetković ${ }^{2}$, Dušica D. Pavlović ${ }^{2}$, Aleksandar Lj. Bojić ${ }^{1}$

${ }^{1}$ Univerzitet u Nišu, Prirodno-matematičkifakultet, Višegradska 33, 18000 Niš

${ }^{2}$ Univerzitet u Nišu, Medicinski fakultet, Bul. Zorana Đinđića 81, 18000 Niš

\section{(Naučni rad)}

Kontaminacija životne sredine teškim metalima predstavlja opasnost za žive organizme. Pošto metali nisu biorazgradivi, ali su rastvorljivi u vodi, oni mogu postati dostupni živim organizmima i može doći do njihove akumulacije u životnoj sredini. Najveća kontaminacija životne sredine teškim metalima javlja se u blizini industrije metala. Teški metali mogu učestvovati u složenim hemijskim i biološkim procesima. Faktori koji utiču na njihovu pokretljivost kroz zemljišne i vodene sisteme su $\mathrm{pH}$, redoks potencijal, priroda sistema, prisustvo različitih materija koje mogu imati ulogu sorbenta, prisustvo i količina organskih liganda, uključujući huminske i fulvo kiseline i prisustvo neorganskih liganda. Procesi vezivanja, transporta, biodostupnosti i mobilnosti jona metala u zemljištu i vodenim sistemima u velikoj meri zavise od interakcije sa huminskim supstancama. Joni metala mogu nagraditi rastvorne komplekse sa huminskim supstancama i tako prouzrokovati kontaminaciju površinskih i podzemnih voda, usled zadržavanja metala u zemljišnom rastvoru. Takođe, može doći i do stvaranja nerastvornih kompleksa, i akumulacije metala u zemljištu i sedimentima. U ovom radu vršena su uporedna ispitivanja kompleksa jona teških metala (Co(II), Ni(II), $\mathrm{Cu}(\mathrm{II}), \mathrm{Zn}(\mathrm{II})$ i Pb(II)) sa huminskom kiselinom. Vrednosti konstanti stabilnosti formiranih kompleksa određene su pomoću Šubertove jonoizmenjivačke metode, koja se zasniva na raspodeli količine metala između smole i vodene faze u sistemima sa i bez prisustva liganda. Ispitivanja su vršena na $\mathrm{pH} 4.0$, temperatura od $25{ }^{\circ} \mathrm{C}$ i pri jonskoj jačini od 0,01

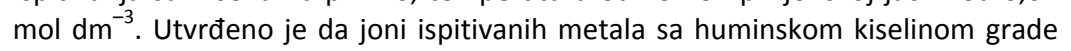
mononuklearne komplekse, 1:1. Dobijene vrednosti konstante stabilnosti formiranih kompleksa prate redosled $\mathrm{Co}(\mathrm{II})<\mathrm{Ni}(\mathrm{II})<\mathrm{Cu}(\mathrm{II})>\mathrm{Zn}(\mathrm{II})$, koji odgovara rasporedu u Irving-Vilijamsovoj seriji jačine vezivanja, koja je određena za dvovalentne jone. Vrednost konstante stabilnosti dobijene za kompleks formiran između $\mathrm{Pb}$ (II) jona i huminske kiseline veća je u odnosu na vrednosti konstanti stabilnosti ostalih ispitivnih kompleksa. Rezultati dobijeni ispitivanjem interakcije jona teških metala sa huminskom kiselinom mogu se koristiti za predviđanje distribucije i kontrolu migracije teških metala u prirodnom okruženju.
Ključne reči: Zagađenje teškim metalima - Huminska kiselina • Konstanta stabilnosti 